\title{
SUSTAINABILITY OF SITE DEVELOPMENT - A REVIEW
}

\author{
AishwaryaG.K ${ }^{1}$, Mohamed Salman Sait ${ }^{2}$, Taiyaba Tabassum ${ }^{3}$, Nithin S.Reddy ${ }^{4}$ \\ ${ }^{1}$ Assistant Professor, Department of Architecture, Dayananda Sagar Academy of Technology and Management, \\ Bangalore \\ ${ }^{234}$ B.Arch. Students of Architecture, Dayananda Sagar Academy of Technology and Management, Bangalore \\ Dayananda Sagar Academy of Technology and Management, \\ Bangalore, India \\ 1aishu_vin@yahoo.com, ${ }^{2}$ salman1994sait@gmail.com, ${ }^{3}$ taiyaba2494@yahoo.co.in, ${ }^{4}$ srininithin@gmail.com
}

\begin{abstract}
'Sustainable development is the development that meets the needs of the present without compromising the ability of future generations to meet their own needs' [1]Sustainability as a focus has reached and touched all realms of design,it has become prerogative and is unavoidable for continuity and wellbeing of all habitat[2]. The field of Architecture, Urban design and Planning are looked into as potential sources of consumption imprinting large ecological footprints[3]. Architecture and planning require the resource for creating places of shelter or storage, for sustenance of habitat which is known as the Site[4]. The site specifically is seen as land in this paper. Landis the source of supply and it s potentials must be retained and maintained to achieve a cradle to cradle effect[5]. The resources, the renewable and non-renewable are consumed for development. By 'cradle to cradle effect' it is meant to achieve means to replenish the earth of the consumed resources. A linear way of using the site tending towards depletion of resources giving no chance for renewable, recyclable, and reusable aspects of design must be avoided. As such the site development plays a crucial role in providing for the current needs, catering to exceeding population as the key issue to address. The exponential growth in population demands for Sustainable site developments for further future development.[6]. This paper restricts it's area of research to eco-technic andeco-centric aspects ofsite sustainability[7].The paper delves into sustainable site development of the site of three sizes. The site development isof various types'residential, institutional,industrial and commercial, to mention a few. The research delves into role of sustainability in site developments in smart cities at global level, site development at regional level stating significance of open spaces in built environment and finally culminates into site planning for designs of much smaller scale. The goal of this paper is to assimilate data pertaining to issues and noteworthy practices through literature survey in a systematic way of site development at identified 3 levels.
\end{abstract}

Keywords: Sustainability, Site Development, Eco-Centric, Eco-Technic, Site Planning

\section{DEFINITIONS}

'Sustainable development' is the development that meets the needs of the present without compromising the ability of future generations to meet their own needs' [1].

'Site' is a specific area identified which may or may not be associated with development[8]; the site may be real or virtual; 'Site' has gained its meaning as a virtual space, which is used for accumulation of data on specific subjects in information and communication technology today. In this paper 'Site' specifically means land, and includes the physical aspects of the resource only;

'Development' is the man made attempt at equipping nature to render it suitable for various uses; these may be either agricultural, as storage, for human habitat or to maintain ecological balance to mention a few. Development targets increased productivity directly or indirectly and aim at improving the existing state of matter. [9][10]Development in this paper would mean creation of built environment or modification of natural environment which may have overlooked, ignored, wrongly prioritised, or may have simply been unaware of its effects. Sustainable development in this paper would delve into aspects of prioritization and systematic layering of issues, at micro and macro scales.

'Resilience' is the ability of a system and its components to anticipate accommodate and recover from a disturbance. A system's resilience is enhanced through the preservation, restoration and improvement of its essential structures and functions. [11]

'Mitigation' refers to taking measures to slow or reverse negative impacts of change.

'Built environment' would mean any manmade intervention on natural environment for livelihood [12]

\section{INTRODUCTION}

From ancient periods site development and site planning have been addressed with importance bringing in a fine nexus between the regional and the local factors affecting the design [13].The Sustainability of Site Development exists in various scales[14]. The development of land at all scales has been extensive, encroaching natural habitats and natural resources depleting and over using them questioning the concept of development itself. The immediate needs has 
gained more importance and assumed the status of prime priority not attending the future needs and creating imbalance of existing state. From the $19^{\text {th }}$ century the need for sustainability[15] has been the target, where 'No Growth' campaigns have not been able to survive or address issues on long term basis.[16]

The paper is divided into 3 parts, the first part of the paper discusses a few identified roles of land and its cue to ideal functions which it may gear itself with. The problems caused by built environment using land on various natural resources are stated. The second states examples where sustainability issues are addressed with practices which are noteworthy. The third and the final section postulate questions which intend to initiate pilot research.

\section{LAND AS A SITE- IT'S ROLE AND FUNCTIONS}

In Sustainable Development of the site, the tangible aspect of the site for the development becomes vital aspect. Land must not be seen independently but as a part of the whole without any neglect to the whole. The site or the land assumes various roles with significant functions. 1) the land as a link where the function of this would be to connect and network many services 2) The land maybe seen as a geography where the function of this would be to identify, allocate and establish its land use 3) land as a director land form and it's relation with water and soil identified as key function 4) land as a generator where the function is related with both the living and the built environment 5) land as a reflector to improve themicroclimate. 6) Finally land as a Real Space Definer, it's function to co-exist with other natural resources, example sunlight and the ecosystem,reinstating it's importance

\section{ISSUES PERTAINING}

TO

\section{SUSTAINABILITY WITH LAND AS A SITE}

Some of the detrimental effects of the built environment on land to the other natural resources are stated as follows- the built environments using lands affects water, food and air, the immediate basic needs for survival; The problems being a) degradation of soil, availability of land; deterioration of plant life and food security, creating imbalance in the ecological

systems; b) flooding and regeneration;and c)effecting microclimate adversely.

\section{MITIGATION METHODS BY NOTED EXAMPLES AT THREE IDENTIFIED LEVELS.}

A few noteworthy examples which have addressed the above problems are mentioned as follows:

\section{A. The First Mixed-Use Development in Kerala, Kozhikode.}

Kozhikode ranks the second best city in India to reside. Itconstitutes $8 \%$ of Kerala's population and is an important trade hub with good connectivity. It generates $12 \%$ to state income. There is a lot of commercial activity seeping into the city.

The cities are expanding, the distances between habitat and workplace, study and other amenities is also increasing. The long distance between these dwellings demand for connectivity through built environment namely roads which cater to transportation. The environmental impact of built environment for transport is significant because it is inducing vehicles which are a major consumer of energy. It uses most of the world's resource. This also creates air pollution. The built environment is an indirect and significant contributor to global warming through emission of carbon dioxide, via transport. Conservation of energy becomes an important aspect and thus, here Mixed Use Development has been chosen. It saves energy and is more sustainable. [17]

Advanced Information and Communication Technology has made viable option of Mixed-Use Developments. These are the best solutionsfor the present scenario of growing needs of future population. Scarcity of land and overconsumption of resources within cities is the main reason why mixed use concept is preferred. It reduces land consumption for connectivity and provision of services. Automobile dependency is also controlled through this method of mitigation.

\section{B. Technology Square Atlanta}

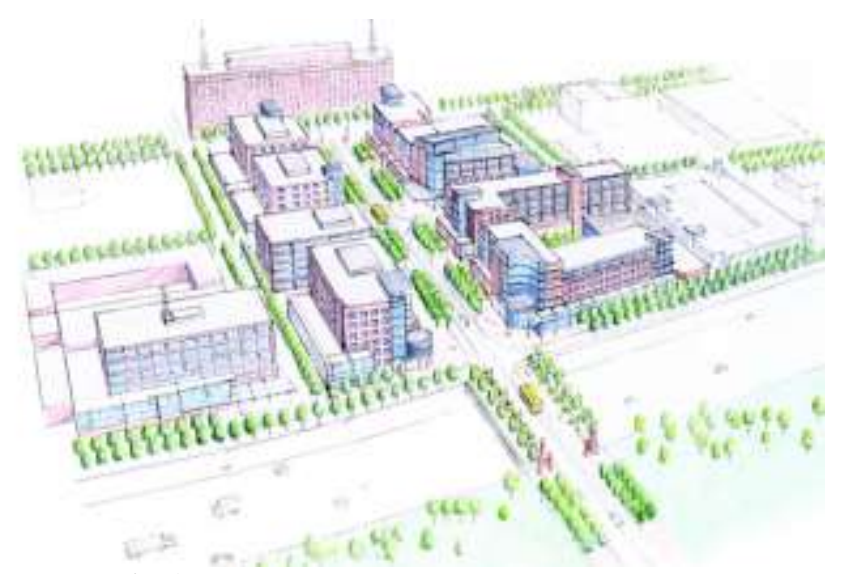

Fig 1. View of Technology Square Atlanta

Atlantahas been afflicted by suburban sprawl for the past half-century.The upshot of this unfettered growth is consuming land, monotonous real estate development, traffic congestion, terrible air quality, and high rates of chronic disease. To tackle these problems developers produced mixed-use projects that refreshed many of Atlanta's neighborhoods. Technology Square [Fig 1], Atlantic Station and Glenwood Park are some of the evident projects.

Taking the example of Technology Square where 1.4 million sq. ft. mixed-use development.This mixed use development has tried to achieve ingenious use of land by lining the shops, cafes, and restaurants, and essentially serves as a new "main street" for both students and the nearby residents. The development includes the college, 
hotel, research building, restaurant and retail store all located in the same community preserving and enhancing our environmental resources. [18]

\section{New York Central Park}

New York Central Park[Fig 2] is an example where the built environment has been sustainably developed keeping in mind the future growth of the city. [19] The park initially opened in 1857, covering 778 acres of land set aside in the central part of borough of Manhattan. Later Frederick Law Olmsted and Calvert Vaux, the winners of the 1858 design competition for Central Park expanded the park to 843 acres with a plan they titled Greensward Plan. [20] The Central Park constitutes $20 \%$ of land of New York City. There are more than 26000 trees, 150 acres of water, and 250 acres of lawn and 136 acres of woodland. It consists of 3 macro habitats: Urban forest, urban aquatic area and urban lawn.

Central Park and its green spaces support and promotes critical environmental services. Environmental services are typically defined as the indirect values that humans receive from ecological processes that help regulate the natural environment. It benefits all forms of life.It mitigates the heat island effect, and helps to manage storm water and provide habitat for diverse wildlife.

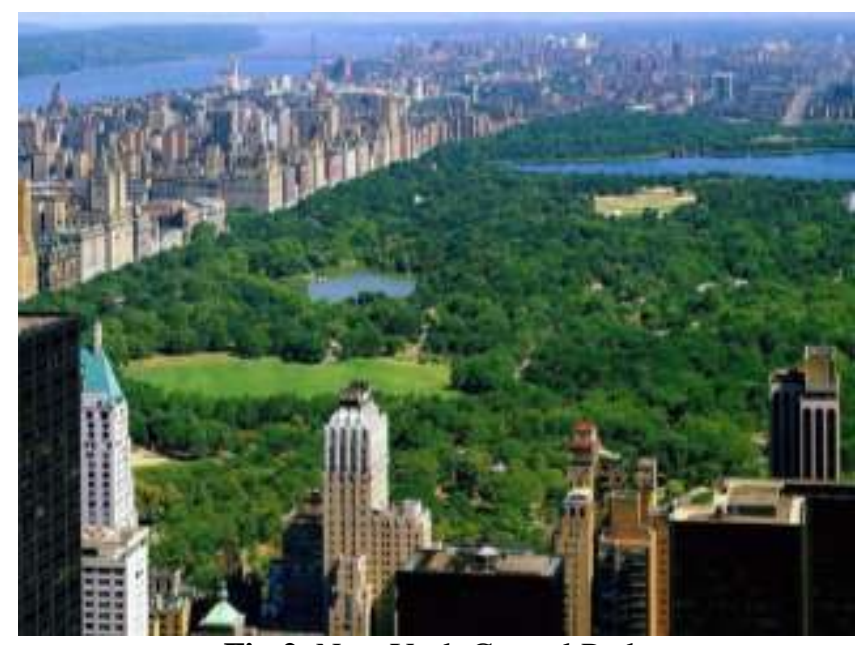

Fig 2. New York Central Park

Central Park is a part of a resilientsystem. A system's resilience is enhanced through the preservation, restoration and improvement of its essential structures and functions. The park has taken informed decisions about strengthening biodiversity by experimenting with planting a number of climate responsivetrees to improve the system. This biodiversity acts as a buffer against disturbances of the habitat. It translates into the vitality and sustainability of changing environments.

Urban trees direct precipitation into the ground, and absorb storm water. Trees, and their associated soil, act as natural filters for water collected in the water bodies present in the park. The park is a green reserve within the city acting as a fundamental aspect, and it is significant to the overall green space.Asalient strategy adopted is the green infrastructure for improving climate by planting vegetation in critical areas to benefit storm water management and reduce the urban heat island effect. When trees are part of a city's infrastructure, managers can build smaller and less expensive storm water retention facilities. [11]

\section{Village Homes, Davis, California:}

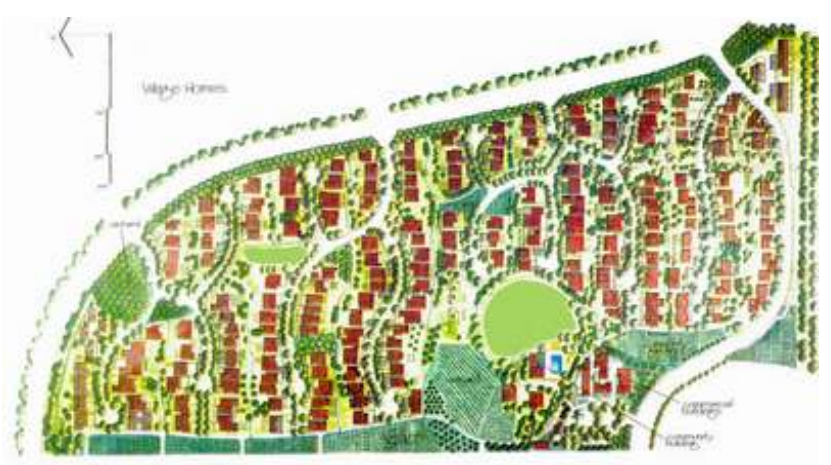

Fig 3. Village Homes, Davis, California

Village Homes [Fig 3] is one of the most widely known built examples of sustainable community design and landscape architecture in the United States. Designed and developed by Michael and Judy Corbett in the 1970s, Village Homes consists of 242 single- and multifamily residences on sixty acres. Houses are planned as energyconserving buildings around common open spaces with play areas and shared gardens. A decent sensible part of the approximately 12 acres development is devoted to community open space, including orchards, vineyards, and play areas. Most of the landscape is designed as an edible landscape and is owned and actively managed by its residents. Village Homes began as the developers' vision in making what they call "a better place to live." Born out of social and environmental concerns of the 1960s and 1970s, Village Homes was intended as a reflection of the values of these times, environmentally sensitive and social responsible. [21]

Based on the principles of sustainable development and ecology as the prime factor, the eco-village concept focuses on the implementation of a human settlement which can be smoothly integrated into the surrounding environment. [22] There are three elements which are relevant to this study. The main site planning innovations of Village Homes is to achieve the element Design closer to nature by incorporating principles such as 1) Neighbourhood agriculture 2) Walking and Bicycling 3) Natural Drainage.

1)Neighbourhood Agriculture: Central green, vineyards, orchards, common areas, Community Gardens, Private courtyards are provided. Vegetation and Edible Landscape incorporated into design.

Much of the plant material in Village Homes is either edible or native. VillageHomes' residents can pick fruit right outside their houses in most common areas. The edible landscape includes oranges, almonds, apricots, pears, grapes, persimmons, peaches, cherries, and plums some of which is sold to local restaurants and markets. [22] 
2) Walking and Bicycling:Pedestrian and bicycle paths were laid out before the streetsand given greater emphasis in the overall plan. This makes it easier to walk or ride bike from one part of the community to another than to drive.

Greatest travel time within the neighbourhood is five minutes, typically without ever crossing a road.

4) Natural Drainage: The drainage system creates a network of small, channels that hold rainwater and allow runoff to seep back into the water table, during the dry summers they become landscaped play areas. The system accomplishes multiple goals. This creates a low-technology drainage system, saves infrastructure costs, and creates pleasant natural areas with visual and play value. [23]

All the above parameters help achieve a design closer to nature.

\section{E. Foot Hill College}

Foot Hill College was designed in the year 1959 by the architects KumpMarsten and Hurd working with Sasaki, Walker, landscape architects. The college caters to 3500 students spread over 122 acres of land. It is situated in the east-facing foothills of the coastal range in Los Altos, California.

Topographically, the site includes of two small hills separated by a ravine.

A looproad and central buildings are planned wellwhich suited the site conditions and prevents fragmentation of land.

The hills were small to so as to accommodate the buildings. 300,000 cubic yards of earth were moved to provide a flat area of about 30 acres.

The reviewers of the project deemed this aspect so successful and remarked on the restraint with which the original land had been treated.They came up with a special landscape for this particular site, which consists of 5 zones

Zone 1 - empty spaces along the boundary where planting was done. Zone 2 - associated with the first zone along with the loop roads and parking areas were planted with orchard scale planting. Zone 3 -comprising of natural grass hillsides in order to maintain the natural quality of the original site.

Zone 4 - open spaces within the enclosures. It was rich and green landscaping was carried out, it was representative of the foothill landscape.Zone 5 - courtyards within the building were given individual identity using paving and ornamental plants.

\section{CONCLUSION}

The finding covers a small fragment of the large knowledge base available and has been a successful attempt in understanding the roles and functions of land as a resource. The land as a sustainable resource is contributing to ecology and environment.Every piece of land along with its built environment has to respond to its context. The research questiontargets the results pertaining to land along with built environment to achieve the same or more sustainable aspects that the land initially has already achieved.For which the analysis of site plays a vital role both before and after the addition of built environment. The quantitative analysis of quality of resource, with built environment as a variable will inform the search, for achieving a cradle to cradle effect. The review establishes that we need land of resilient nature, for sustainable development, at present and in future, in good quantity. Further the review helps identify the research question of which land is suitable for which function, with what type of sustainable development. With this established, the wise use of land may be promoted.

\section{ACKNOWLEDGEMENT}

The authors would wish to thank Dr.Lakshmikanth Principal of Dayananda Sagar Academy of Technology and Management for providing a platform and encouraging us to participate in the National Conference Green Computing Technologies. We would like to thank, The Dean of School of Architecture for having spent time, listening and sharing insightful thoughts which directed the review to be focused, yet expansive. And last but not the least our heartfelt acknowledgements to professors of School of Architecture Prof. Gaddam.D.Ramesh, and Prof M.V.Janardhan Rao for their continuous support and encouragement.

\section{REFERENCES}

[1]Our Common Future,pg8, World Commission on Environment and Development (Oxford, Great Britain: Oxford University Press, 1987) (Brundtland report)

[2]Webster`s New International Dictionary,Springfield, Mass: Merriam-Webster Inc., 1986

[3]Monto Mani and B.V. Venkatarama Reddy "Sustainability in Human Settlements: Imminent Material and Energy Challenges for Buildings in India"Journal of the Indian Institute of Science,A Multidisciplinary Reviews Journal

ISSN: 0970-4140 Coden-JIISAD C Indian Institute of Science,

[4]Cambridge Dictionary Online Available http://dictionary.cambridge.org/dictionary/british/site

[5]William McDonough,Michael Braungart" Cradle to Cradle: Remaking the Way We Make Things"North Point Press. 2002

[6 ] Andres Duany, Jeff Speck with Mike Lydon "The Smart growth manual", New York, Mc Graw Hill, 2010

[7] Simon Guy, Graham Farmer "Reinterpreting Sustainable Architecture: The Place of Technology" Journal of Architectural Education, Volume 54, Issue 3, pages 140148, February 2001

[8] Cambridge Dictionary Online Available, http://dictionary.cambridge.org/dictionary/british/site [9][10](http://en.wikipedia.org/wiki/land_development) (http;//dictionary.cambridge.org/dictionary/businessenglish/development- land) 
[11]Climate Change Planning Master of Science in Sustainability Management, Columbia University 2011.

[12]Built environment - Wikipedia, the free encyclopaedia http://en.wikipedia.org/wiki/Built_environment

[13]Vitruvius"The Ten Books of Architecture, translated by Morris Hicky Morgan, London, Harvard University Press 1914

Alberti, Leon Battista, On the Art of Building in Ten Books, trans. Joseph Rykwert,Neil Leach, Robert Tavernor (Cambridge, Mass.: The MIT Press, 1988.

Chanakya"Arthashastra",http://www.esamskriti.com/essaychapters/Town-Planning-and-Public-Administration- -

Arthashastra-1.aspx

[14]Natural Park Service, Forwarded by Bruce BabbitEco system Management for Sustainability, Principles and Practices Illustrated by Regional Biosphere, Reserve Cooperative.1994,

[15]Danold Watson -Sustainable Design- Time Saver Standards for Urban Design

[16]Andres Duany, Jeff Speck with Mike Lydon "The Smart growth manual", New York, Mc Graw Hill, 2010

[17] K R Iyer, Kerala's First Mixed Use Development Taking Shape in Kozhikode, 2012. [Online] Available: http://property.sulekha.com/kerala-s-first-mixeduse-development-taking-shape-in-kozhikode_592613_blog [18]Joshua D. Herndon, Applied Research Paper, Dr. William Drummond, "Mixed Use Development in Theory and Practice: Learning from Atlanta's Mixed Experience", May 5, 2011, pg. 54, 55, 56

[19]Arthur B. Gallion, Simón Eisner,Stanley Eisner "Urban Pattern"Wiley; (March 1, 1993)

[20] Homepage - The Official Website of Central Park NYC www.centralparknyc.org/

[21]www.earthfuture.com/community/villagehomes.asp

[22]http://arch.ced.berkeley.edu/vitalsigns/workup/siegel_ho use/vh_bkgd.html

[23]http://www.context.org/ICLIB/IC35/Browning.htm 